Article

\title{
Bad Religion as False Religion: An Empirical Study of UK Religious Education Teachers' Essentialist Religious Discourse
}

\author{
David R. Smith ${ }^{1}$, Graeme Nixon ${ }^{1, *(1)}$ and Jo Pearce ${ }^{2}$ \\ 1 School of Education, University of Aberdeen, Aberdeen AB24 3FX, UK; davidsmith@abdn.ac.uk \\ 2 UCL Institute of Education, University College London, London WC1H 0AL, UK; j.pearce@ucl.ac.uk \\ * Correspondence: g.nixon@abdn.ac.uk
}

Received: 15 October 2018; Accepted: 13 November 2018; Published: 15 November 2018

\begin{abstract}
We argue that there is a well-intentioned-yet mistaken-definitional turn within contemporary cultural discourse in which 'true' religion, being essentially loving and peaceful, is distinguished from 'false' religion. Concerned with the possibility that this discourse might be prevalent in school Religious Education (RE), we surveyed practicing RE teachers within the United Kingdom (UK) on their beliefs about religion. We wanted to see how far the surveyed teachers evidenced a strand of contemporary cultural discourse which, we argue, conceptualizes bad religion as false religion. Responses from 465 teachers to our online survey indicate that many RE teachers understand religion(s) as essentially benign or pro-social—and present it/them as such in the classroom. We argue that RE can only foster religious literacy if religions are presented as multifarious, complex, social phenomena. This cannot be predicated upon an essentialist conceptualization of harmful religion as false religion, which is inimical to understanding religion in the world today-as in times past. We conclude that this conceptualization is a barrier to UK RE meeting both its extrinsic purpose to educate, and one of its intrinsic purposes to foster tolerance and pro-social attitudes.
\end{abstract}

Keywords: religion; Religious Education; essentialism; UK schools; religion and schools; teacher beliefs

\section{Introduction}

We teach general tolerance to all people, of all religions and that all religions teach peace, love and compassion, with the odd exception where there may be extremists who misinterpret their holy books, but that they exist within all religions and that they are not true followers. [English Secondary Academy/Free School Teacher]

Aspects of contemporary religious, politico-cultural, discourse distinguish between true, or genuine, religion which is by its very nature good; and its opposite, which is dangerous, bad-and therefore false- or not genuine religion. Religious and political leaders often stress that terrorist atrocities that are putatively motivated by religion, do not in actuality reflect a true understanding of the religion in question. Consider, for example, the Dalai Lama who delineates between terrorism and violence on the one hand; and being a "genuine practitioner" of religion on the other:

Buddhist terrorist. Muslim terrorist. That wording is wrong. Any person who wants to indulge in violence is no longer a genuine Buddhist or genuine Muslim, because it is a Muslim teaching, you see, once you are involved in bloodshed actually you are no longer a genuine practitioner of Islam. All major world religious traditions carry the same message: the message of love, compassion, forgiveness, tolerance, contentment, self-discipline-all religious traditions. (Dalai Lama 2016 [Emphasis added]) 
The nature of religion for the Dalai Lama is essentially good—with "all major" religions espousing the "same [positive and pro-social] ... message [of] ... love, compassion, forgiveness, tolerance, contentment, self-discipline". The essence of "genuine" religion is non-violent. As such, purported violent manifestations of religion must constitute false religion.

Similarly, former US President Barack Obama (2016), when asked why he refuses to use the term "Islamic terrorist", explained that ISIL has "perverted and distorted, and tried to claim the mantle of Islam for an excuse for, basically, barbarism and death". He went on, "There's no religious rationale that would justify in any way any of the things that ... [ISIL] do". For Obama, the nature of true religion precludes any possibility of atrocity, as Obama conceptualizes it; despite the indisputable fact that ISIL claim a religious rationale for their actions (Hashim 2014). Likewise, United Kingdom (UK) Prime Minister, David Cameron MP, speaking of the "poisonous ideology of [Islamic] extremism" which has "become an epidemic - infecting minds from the mosques of Mogadishu to the bedrooms of Birmingham" similarly essentializes religion, sanitizing it of violent extremist ideology: "[T]his extremist ideology is not true Islam. That cannot be said clearly enough" (Cameron 2017a [Emphasis added]). With this caveat, however, Cameron seeks to explain how extremists can self-identify with "Islam ... a religion of peace":

It is not good enough to say simply that Islam is a religion of peace and then to deny any connection between the religion of Islam and the extremists. Why? Because these extremists are self-identifying as Muslims. From Tunisia to the streets of Paris, these murderers all spout the same twisted narrative that claims to be based on a particular faith. To deny that is to disempower the critical reforming voices that want to challenge the scriptural basis on which extremists claim to be acting - the voices that are crucial in providing an alternative worldview that could stop a teenager's slide along the spectrum of extremism. We can't stand neutral in this battle of ideas. (Cameron 2017a [Emphasis added])

A pragmatic tone pervades Cameron's thinking: in order to provide an "alternative worldview", it requires hermeneutical engagement to challenge the "scriptural basis upon which extremists claim to be acting". While previously explicit (Cameron 2017a), it is possible to discern implicit notes of essentialism in Cameron's casting of extremist ideology as a "twisted narrative". In this instance, the twisting that Cameron describes could be understood as misrepresentation; thus, pointing to an essentialist understanding. In his speech at Ninestiles School (UK), Cameron is again clear in his essentialist conceptualization of religion in distinguishing between "Islamist extremism" and "Islam the religion" (Cameron 2017b).

From religious leaders, such as the Dalai Lama; to political leaders, like President Obama and Prime Minister Cameron, extremist violence is conceptualized as a manifestation of bad, that is false, religion; for religion has a nature-an essence—which is peaceful, loving, and good.

\section{What's Wrong with Essentializing Religion?}

Essentializing religion, reifying it, or turning it "into a thing" (Smith 1962) with a nature or essence, is problematic, for it erroneously harmonizes and stagnates multifarious and dynamic religious beliefs and traditions. ${ }^{1}$ Essentializing religion syncretizes distinctiveness, presenting religion as espousing the same message, due to a supposed commonality (Cf. Dalai Lama 2016). Religious essentialism distorts the diverse phenomenon of religion and hampers understanding of the kaleidoscope of religious expression, evidenced across time and place. Such essentialism may manifest itself in regard to

1 Cf., Schaffalitzky de Muckadell (2014) who whilst accepting the "diversity and mutability of religion" (Schaffalitzky de Muckadell 2014, p. 502) argues for an essentialist definition of 'religion' as a category: "the fact that religious traditions are constantly changing does not mean that the category 'religion' is changing" (Schaffalitzky de Muckadell 2014, p. 503). While not disputing this specific premise, Schaffalitzky de Muckadell's theoretical argument does not sufficiently engage with religious traditions from a historical perspective: the very phenomena that Schaffalitzky de Muckadell seeks to categorise. 
instantiations of specific religions, as seen in Panjwani's and Revell's discussion concerning both the negative and positive essentialization of Islam (Panjwani and Revell 2018). It may also manifest itself in the broader treatment of religion as a wider phenomenon. In what follows, we explain why we consider the reification of religion (the harmonization, and petrifying, of multifarious and dynamic traditions) to be erroneous and deeply problematic.

From a historical perspective, within Christianity, the religious texts that are being interpreted vary, for the Biblical Canon, or measuring rule, is differently constituted depending on Christian tradition across time and place. A diversity of religious traditions intersect with rich histories of interpretation. For example, the parting of the Ways between Early Christianity(ies) within Judaism(s) is a matter of scholarly debate ${ }^{2}$. Some scholars view Jesus as the fulfilment (and superseding) of Torah; ${ }^{3}$ while others argue that Jesus intensified Torah. ${ }^{4}$ For some, Christianity is pro-social and supports heterosexual conceptions of family and matrimony as a religious sacrament (Cf. Roman Catholic Doctrine); yet, in contrast, one might highlight Jesus's fictive kinship and his sowing of enmity within family relationships (Matthew 10:35). ${ }^{5}$

Pauline Christianity supplants former religious identities with a new "in Christ" identity-declaring that "Jew" and "Greek" no longer exist (Galatians 3:28), transforming the traditional binary antitheses of the First Century symbolic universe; yet some forms of contemporary Christianity (i.e., Zionists) interpret the Bible as preferencing modern-day Jews, with the State of Israel as part of a Divine plan. While some argue that the Apostle Paul anticipates the death of an incestuous Corinthian (1 Corinthians 5:5) via a curse (Smith 2009); others, for example, do not envisage violence, but rather excommunication (Garland 2003, p. 154).

For some, the story of Christian Salvation History is one in which human beings exercise free will (Cf. Arminianism); while for others (notably, Calvinist articulations), it is a pre-destined response to grace. In some Christian theologies, all of humanity is saved (Universalism); while in others, there is the violence of Annihilation; ${ }^{6}$ while yet still for others, the lasting violence of Hell. ${ }^{7}$ If religion has any 'essence' at all, it is arguably in its diversity and plurality. Religion is not "a thing" and we should resist the reification of it (Smith 1962). Religion can only be essentialized by ignoring nuance, or by opting for a "selectively true" (Revell 2012) account of religion.

Both negative and positive essentialist conceptualizations of religion exist. ${ }^{8}$ In light of the strand of cultural discourse outlined above, our concern is with the latter. In seeking to essentialize religion and to proscribe it with a set of positive, pro-social, attributes, the self-understanding of some religious adherents is unjustifiably discounted-and religion is sanitized by being cleansed of any negative, anti-social, connotations. Consider again, the Dalai Lama (2016), who sets up a binary between non-violent "genuine" religious practitioners; and violent non-genuine religious practitioners. Contrary to his portrayal, the extent of the influence that religious belief has in encouraging violence is broadly assessed by scholars. Some see terrorism as predominantly a product of ethno-nationalism and economic injustice (Gunning and Jackson 2011; Hasenclever and Rittberger 2000); others argue that we must recognize the self-understanding of protagonists and the possible influence of certain beliefs, for example, about eschatology/salvation/identity/truth, which may contribute to behavior perpetrating terrorist incidents (Rapoport 1983).

2 Cf., Dunn (2015).

3 E.g., Banks concludes that the Law in Matthew 5:17 has the function of "pointing forward to that which as now arrived in its place" (Banks 1974), namely Jesus. In Jesus' teachings, the Law has been fulfilled, and so transcended (Banks 1974, p. 231). See also Riches: "The intensification of the Law leads to its replacement by a new, more radical, law" (Riches 1996).

4 Cf., Martin (1993): “There are in the first place no antitheses because in the second place there is no overturning of Torah. Jesus, according to Matthew, neither dismissed the Torah nor released his followers from its imperatives".

5 Cf., Martin who posits an eschatological context for this logion: Martin (2013).

Cf., William Temple, the late Archbishop of Canterbury: Temple (1924).

Cf., Evangelical Alliance Commission on Unity and Truth among Evangelicals (2000).

8 Cf., Hitchens (2008). 
Violence in the name of religion is well established. Pope Urban II's command to crusade in 1095 described Muslims as a "despised and base race" to be conquered (Winant 2004, p. 139). Within Hinduism, Thugs killed to be witnessed by Kali; within Islam, assassins were commissioned to bring about Muslim social order and purity; and within Judaism, Zealots were prepared to use violence to precipitate the end of days (Rapoport 1983). Prominent Christian leaders, such as Augustine and Aquinas, theologically conceptualized circumstances in which war, or large-scale violence, could be considered "just" in the eyes of God. In the present time, the Catholic Church's 1992 Catechism similarly provides a foundation for violent action through the medium of "military force" (Catechism of the Catholic Church (Paul 1994, para. 2309)).

Sedgwick (2010), writing about Al-Qaeda, a 20th Century religio-political movement, argues:

[A]l-Qaeda is a distinctively Islamic group. Not only is its chosen constituency a confessional one, but al-Qaeda also uses-and when necessary adapts—-well-known Islamic religious concepts to motivate its operatives, ranging from conceptions of duty to conceptions of ascetic devotion. (Sedgwick 2010, p. 795)

In contrast, some scholars have challenged the modern concept of Religious Terrorism, arguing that such increasingly lethal violence has, as its root causes: nationalism; ethnic division; and perceived economic injustice (Pape 2005; Sageman 2011; Hoffman 2006; Masters 2008). Others have posited that the secular/religious (or political/spiritual) binary is too complex to delineate terrorism as principally religious (Gunning 2007; Gunning and Jackson 2011; Cavenaugh 2004a, 2004b; Smith 1962; Fitzgerald 1997; Eickelman and Piscatori 1996; Robinson 1997; Sayyid 2003; Adib-Moghaddam 2009). However, to seek to isolate strands of belief: religious belief from nationalism, for example, as if dealing with chemical elements, is to fail to recognize the complex ways in which theological understandings are not reified, but permeate thinking.

Whilst acknowledging the complex social realities in which violence manifests itself, it is possible to discern the enabling role that certain religious thinking can have; for example, in "facilitating the demonization of the enemy, promoting a zero-sum mentality, motivating (and reaching) the faithful and creating an in-group identity" (Hasenclever and Rittberger 2000). This is not to argue that religion is essentially bad, or anti-social; but rather, that it is a diverse, multifarious, and dynamic phenomenon.

In the light of what we have argued thus far, educating children and young people about religion, which schools in the UK (as elsewhere) are legally required to do, provokes significant challenges and questions. Fundamentally, it raises a question about UK RE teachers' conceptualizations of religion. Teaching can be understood as a sociocultural activity in which teachers are not hermetically-sealed from their wider cultural contexts. Rather, teachers exist within a specific socio-cultural milieu and contribute to meaning-making within a learning environment. Having identified aspects of contemporary cultural discourse in which religion is reified and ascribed with essential goodness: do UK RE teachers similarly conceptualize religion? Before we empirically explore this question, we consider the curricular and statutory articulation of RE across the UK's four countries.

\section{Religious Education in the United Kingdom (UK)}

The history and development of RE in the UK (and indeed across much of Europe) is one in which the subject traditionally was organised under the aegis of Christian churches. In the face of multiple changes within social, economic, and educational spheres-RE increasingly has been demitted to the control of the state, with the control of the churches having simultaneously (to lesser or greater extents) diminished, though between and within the four jurisdictions or nations that make up the UK (England; Northern Ireland; Scotland; and Wales) there are interesting variations. For example, whilst in Scotland, the Church of Scotland handed over control of Presbyterian parish schools in 1872 to the Scottish Educational Board with provisos guaranteeing weekly worship; a right of conscientious withdrawal; and a mandatory lesson in what was then termed "religious instruction"; the Roman Catholic church only handed over fiscal control to the state in 1918, retaining primacy in determining 
the catholicity of denominational schools (which make up about 15\% of Scottish schools) (Nixon 2013). Meanwhile in Northern Ireland, the Religious Education Core Syllabus is exclusively defined and written by four Christian denominations (Anglican, Catholic, Methodist, and Presbyterian) without state involvement, or, indeed, other faith and belief communities or other interested parties being consulted (Richardson 2008).

Nevertheless, despite such diversity, it is fair to say that RE in UK schools has, since the early 1970s, emerged increasingly as an educational, rather than a confessional (as was previously the case), presentation of multiple traditions and ideologies. England and Wales' Durham Report (Commission on Religious Education in Schools 1970) and Working Paper 36 (Schools Council 1971), and Scotland's Millar Report (Scottish Education Department 1972) intended to address the perceived failings of Religious "Instruction" ${ }^{9}$ in increasingly pluralistic and secular English and Scottish contexts, respectively. These reports appeal to educationalists advocating a learner-centered non-confessional approach to RE. They argued for the professionalization of RE teachers and the establishment of professional bodies (Advisors) to oversee subsequent development in the subject. These influential reports advocated an exploratory approach rather than a confessional one. It is fair to say that non-denominational RE in these jurisdictions, since the publication of said reports in the 1970s, has been the story of the attempt to enact their recommendations.

In the face of social change globally, including throughout Europe, Educationalists have examined and re-appraised the place and influence of religion in education and moved towards an increasingly multi-religious, impartial, pupil-centered, philosophical, and ethics-centered presentation of the subject (Nixon 2013). The Toledo Guiding Principles (The Office for Security and Co-Operation in Europe 2007), in describing the societal and international events that prompted such a publication, outline the need to meet the challenges of the processes of migration; to avoid misconceptions about religion and belief, resulting from ignorance and recent history (particularly the events of 11 September 2001), and to enhance international security through the development of tolerance. The core principles of the Toledo document are the right of everyone to freedom of speech and conscience, and that knowledge of religion and belief is foundational to combating prejudice and fostering community cohesion. While these principles are reasonable and well-intentioned, they carry a risk: if RE is principally conceputalized instrumentally as combating prejudice and fostering community cohesion, rather than as the pursuit of knowledge and understanding of religion; there is a risk that knowledge is selected to serve instrumental goals and is thereby distorted. There is also the danger of anti-social elements of some manifestations of religion which do not serve an instrumental, pro-social, purpose being omitted.

The three-year UK AHRC ${ }^{10} /$ ESRC $^{11}$ Religion and Society project: "Does RE Work?" (Conroy et al. 2013), presented an evolution in RE away from studying the phenomenon of religion towards a more dialogic, or learner-centered, approach. Conroy et al. suggest the multiple aims of RE are to develop religious literacy, defined as: addressing citizenship education; raising multicultural understanding; promoting shared values (denominational or non-denominational); promoting philosophical understanding and skills; fostering cultural and historical literacy; and contributing to moral maturation.

A survey of RE guidance and policy within the UK's four jurisdictions supports Conroy and others' analysis: there is a range of expectations placed upon the subject (Cf. Table 1):

9 The move from the term 'Religious Instruction' to 'Religious Education' is indicative of the subject's transition from a confessional to a non-confessional conceptualization.

10 Arts Humanities Research Council.

11 Economic and Social Research Council. 
Table 1. UK Religious Education Government Guidance.

\begin{tabular}{|c|c|}
\hline Jurisdiction & RE Guidance \\
\hline England & $\begin{array}{l}\text { Religious Education provokes challenging questions about: the ultimate meaning and } \\
\text { purpose of life; beliefs about God; the self; the nature of reality; issues of right and wrong; } \\
\text { and what it means to be human. It can develop pupils' knowledge and understanding of } \\
\text { Christianity, of other principal religions, other religious traditions and worldviews that offer } \\
\text { answers to questions, such as these. } \\
\text { RE also contributes to pupils' personal development and well-being and to community } \\
\text { cohesion, by promoting mutual respect and tolerance in a diverse society. RE can also make } \\
\text { important contributions to other parts of the school curriculum such as citizenship, personal, } \\
\text { social, health, and economic, education } \\
\text { (Department for Children, Schools and Families 2010). }\end{array}$ \\
\hline $\begin{array}{l}\text { Northern } \\
\text { Ireland }\end{array}$ & $\begin{array}{l}\text { Religious Education provides young people with the opportunities to learn about, discuss, } \\
\text { evaluate and learn from, religious beliefs, practices, and values. Through Religious } \\
\text { Education, young people are able to develop a positive sense of themselves and their beliefs, } \\
\text { along with a respect for the beliefs and values of others. } \\
\text { The curriculum for Religious Education is defined by the Department of Education and the } \\
\text { four main Christian Churches in Northern Ireland in the Core Syllabus. It also has a role to } \\
\text { play within the context of the revised curriculum, through presenting young people with } \\
\text { chances to develop their personal understanding and to enhance their spiritual and ethical } \\
\text { awareness (Council for the Curriculum, Examinations and Assessment 2015). }\end{array}$ \\
\hline Scotland & $\begin{array}{l}\text { Religious and Moral Education enables children and young people to explore the world's } \\
\text { major religions, and views which are independent of religious belief and to consider the } \\
\text { challenges posed by these beliefs and values. It supports them in developing and reflecting } \\
\text { upon their values and their capacity for moral judgement. Through developing awareness } \\
\text { and appreciation of the value of each individual in a diverse society, Religious and Moral } \\
\text { education engenders responsible attitudes to other people. This awareness and appreciation } \\
\text { will assist in counteracting prejudice and intolerance, as children and young people consider } \\
\text { issues, such as sectarianism and discrimination more broadly (Scottish Government 2008). }\end{array}$ \\
\hline Wales & $\begin{array}{l}\text { Religious Education in the Twenty-First century encourages pupils to explore a range of } \\
\text { philosophical, theological, ethical, and spiritual questions in a reflective, analytical, balanced } \\
\text { way that stimulates questioning and debate. It also focuses on understanding humanity's } \\
\text { quest for meaning, the positive aspects of multi-faith/multicultural understanding and } \\
\text { pupils' own understanding and responses to life and religion. Religious education in the } \\
\text { twenty-first century consists of an open, objective, exploratory approach but parents } \\
\text { continue to have the legal right to withdraw their children. } \\
\text { (Welsh Assembly Government 2017) }\end{array}$ \\
\hline
\end{tabular}

It is also the case in many schools that there is an expectation that RE contributes to areas of school life which foster community cohesion (both within and outside of school). This can be seen not only in expectations relating to charity work, but also in terms of the on-going conflation of RE with worship in schools-Religious Observance (RO) in Scotland, and Collective Worship in England, for example. Indeed, Nixon's (2018) research into conscientious withdrawal from RE in Scotland revealed that many Head Teachers regard RE and RO as one and the same; as areas of the school life where certain agreed values are shared, explored, and developed. Conroy et al. (2013) make the case that these purposes or expectations of RE are unrealistic; they can lead to a compromised presentation of religious phenomena, and an instrumentalization of the subject; albeit for well-intentioned purposes. Furthermore, Conroy et al. argue that there are opportunity costs and caveats to placing so many expectations on RE which include:

1. Respect being given prominence over understanding;

2. The essentialization of religious phenomena as a "cabinet of curiosities";

3. A failure to examine and consider the "rough edges" of religious phenomena;

4. A lack of critical awareness of religious phenomena. 
The "Does RE Work?" project (Conroy et al. 2013) suggested that how this manifests itself in terms of RE curricula and pedagogical approach is a matter of local determination. RE, like other subjects, has a number of purposes. Discussions about the nature and purpose of History, for example, parallel debate about whether RE should be studied for its own sake or for some wider set of purposes (Smith 2018). It could be argued that the idea of the intrinsic worth of disciplines is reflected in Eliot's notion of autotelic subjects (Baldick 2008) which should be studied either because they map out an agreed phenomenon, or because generating knowledge in that discipline is of intrinsic value. For Smith, speaking about the Scottish curriculum, there is a risk of instrumentalization by stealth and a dilution of disciplinary integrity.

We can, perhaps, distinguish between intrinsic aims (inherent within the discipline) and extrinsic (addressing some wider social function); the "aims of education" and the "aims of subject disciplines" (Lee 2011). Therefore, one may study the phenomenon of, for example, religion and this may develop or sustain many social goals (as posited above) which, it could be argued, are consequential of a good education. However, the discipline, (in Smith's case, he is principally discussing History) must be true to itself and not make such collateral consequences its substantive aim.

In the case of RE, as already indicated, we contend that this risk is no less real, and this is something that the findings of the "Does RE Work?" (Conroy et al. 2013) project seem to bear out. If RE is increasingly driven by extrinsic demands, then this may be an instrumentalization of the subject towards a different epistemic understanding, where the study of religion is less about religious belief, practice, and action, as social facts; but more about a presentation of those that serves extrinsic forces.

The statutory obligation on UK schools to prevent, and report on, the radicalization of young people has a particular locus in RE. UK Government guidance advises teachers about identifying radicalization or "single narrative thinking"; it has also developed an approach to so-called "fundamental British values" (Department of Education 2015). Arguably, this recent development represents a further expectation that RE nurture pro-social thinking, and that the subject support a positive presentation of certain beliefs in RE lessons. In relation to this, as well as to the essentialist strand in contemporary cultural discourse discussed earlier, the authors of this paper, working in two different universities offering Initial Teacher Education in Scotland and England, sought to investigate how teachers of RE conceptualize religion.

\section{Presentation of Data}

This empirical research, based on survey responses ( $n=465$ after exclusions) in 2017 from currently practicing RE teachers, principally from all four UK jurisdictions (three Respondents were from the wider European Union, beyond the Republic of Ireland) sought to establish to what extent (if at all) UK RE teachers essentialize religion: conceptually distinguishing, for example, between good/true/genuine religion-and bad/false religion? RE teachers who were not currently teaching in a school environment were excluded from participation in the survey, as the concern underpinning this research was with contemporary RE classroom practice. The exclusion was affected by the initial two questions of the survey which had as a requirement to be 'currently employed as a teacher' (Question 1) and specifically a teacher of RE in a school (Question 2).

RE in the UK is taught by teachers to children in Early Years/Primary and Middle through to Secondary (or High) school. As such, although "RE Teacher" in the UK can refer to a Secondary school teacher (who often possess a specialist university degree in religion, or a cognate area), for the purposes of this study, we included all of those who teach RE within schools: from Primary to Secondary (High) School (including Sixth Form Colleges).

A UK-wide geographical coverage was sought in order to allow for socio-cultural variation within the UK (Cf. the previous discussion of RE within the United Kingdom). Due to the wide geographical scope of the data collection, an online survey was employed. This research method provided anonymity which afforded Respondents the opportunity to express views without fear of opprobrium in the contested domain of religion. Quantitative and qualitative data was sought: the 
latter through open-text comment boxes which provided the ability to offer further explanation and nuance to a given question. While Respondents were drawn from across the UK, the data was most heavily weighted towards England $(N=323$ or $70.99 \%)$. As the largest population group within the $\mathrm{UK}$, this is unsurprising.

The majority of Respondents had been teaching for 6-10 years ( $N=124$ or $26.96 \%$ of Respondents). Sectoral coverage (displayed in Figure 1) captured the multifarious nature of school provision in the UK (and, especially, in England); excluding 14 other responses which could not be categorized (e.g., "State Catholic"), the majority of Respondents taught in the Secondary state school sector $(N=235$ or $52.57 \%)$. Overall, excluding other responses, Secondary school teachers represented $81.21 \%(N=363)$ of responses with a further $18.79 \%(N=84)$ of teachers in Primary/Junior/Middle schools. The general pattern in the UK is for Secondary school teachers to receive subject specialist education and to largely teach in that subject area, while Primary/Junior and Middle school teachers frequently teach the whole curriculum. As such, it is unsurprising that survey responses are weighted towards Secondary school teachers who more readily identify in the UK as RE subject specialists.

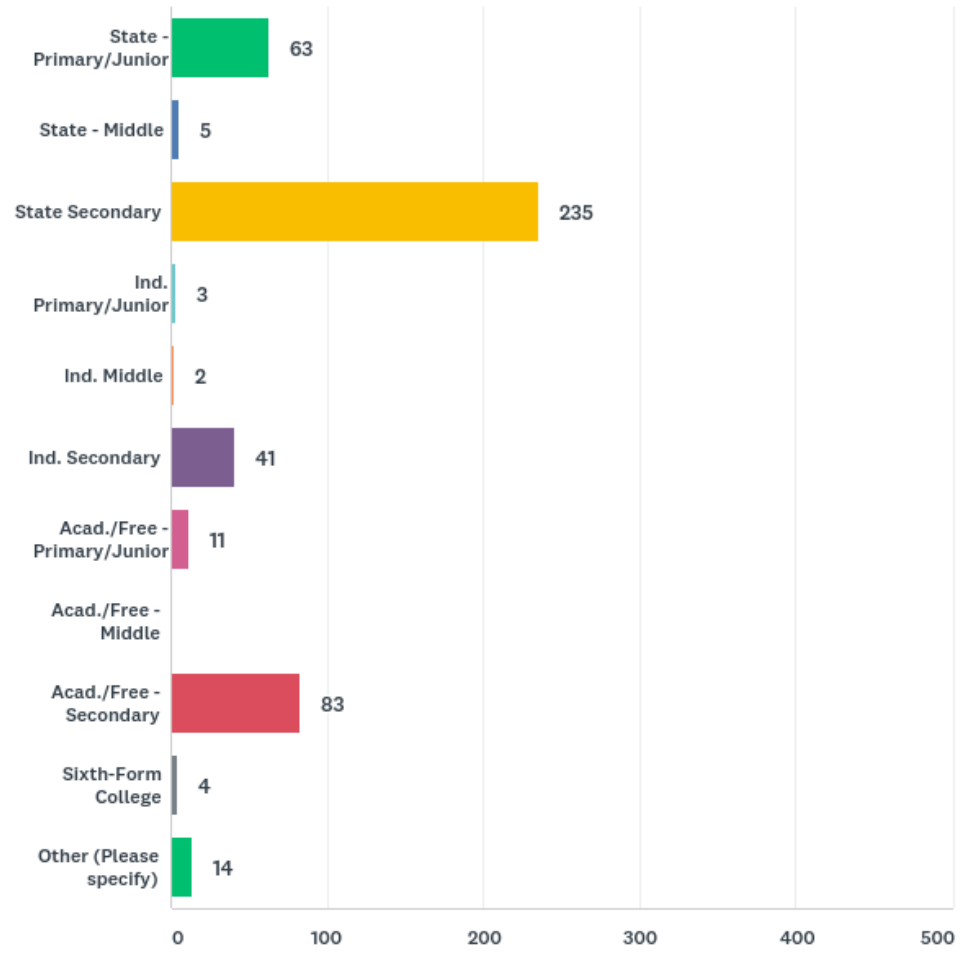

Figure 1. Question 4: Which school sector do you work in? $(N=461)$.

The geographical location of Respondents was weighted towards Urban $(N=178$ or $38.70 \%)$, and Suburban, areas ( $N=191$ or $41.52 \%)$. Respondents came from a variety of degree backgrounds; however, a "Religious Studies" university degree background was the majority response $(N=188$ or $41.50 \%$ ). Respondents were concentrated between ages 25 and 54 (Ages 25-34: $N=144$ or 31.79\%; $35-44: N=142$ or $31.35 \% ; 45-54: N=100$ or $22.08 \%$ ). Female Respondents outweighed males by 388 (or $74.45 \%$ ) to 115 (or $25.33 \%$ ). ${ }^{12}$

In the last UK General Election (2015), Respondents voted for a spectrum of political parties. Of those who chose to vote, the Labour Party received the greatest number of responses $(N=190$ or $42.89 \%$ ). Respondents overwhelmingly identified as “White: English/Welsh/Scottish/Northern

12 This ratio resembles the teaching workforce ratio in England, where approximately $75 \%$ of the School Teacher Workforce in 2017 were women (Department for Education 2017). 
Irish/British" ( $N=389$ or $85.87 \%$ ). In relation to sexual orientation, "heterosexual/straight" comprised 91.05\% $(N=407)$ of Respondents. Concerning the "religious character" of the Respondents' schools, the majority did not have a religious character $(N=278$ or $61.92 \%)$.

Two unipolar 5-point rating-scale questions out of a thirty-question dataset are the principal focus of this paper: Question 23: "Religion is Dangerous"; and Question 24: "Religion should be taught in a positive way in Religious Education". Unforced qualitative free text comments supplemented each of the two quantitative responses.

\subsection{Question 23: "Religion Is Dangerous"}

A total of 389 Respondents used a unipolar 5-point Likert scale to respond to the statement: "Religion is dangerous", "Religion" being employed as a collective noun. In context, the previous questions concerned Christianity (Question 20), Buddhism (Question 21), and Islam (Question 22): as such, no one religion or intra-religious expression was implied in Questions 23 and 24.

As can be seen in Figure 2 the majority of Respondents chose "Not at All" ( $N=144$ or 37.02\%). Overall, the balance of responses represents either outright disagreement ("Not at all") or only "slight" agreement $(N=109$ or $28.02 \%)$ : $N=253$ or $65.04 \%$ when aggregated.

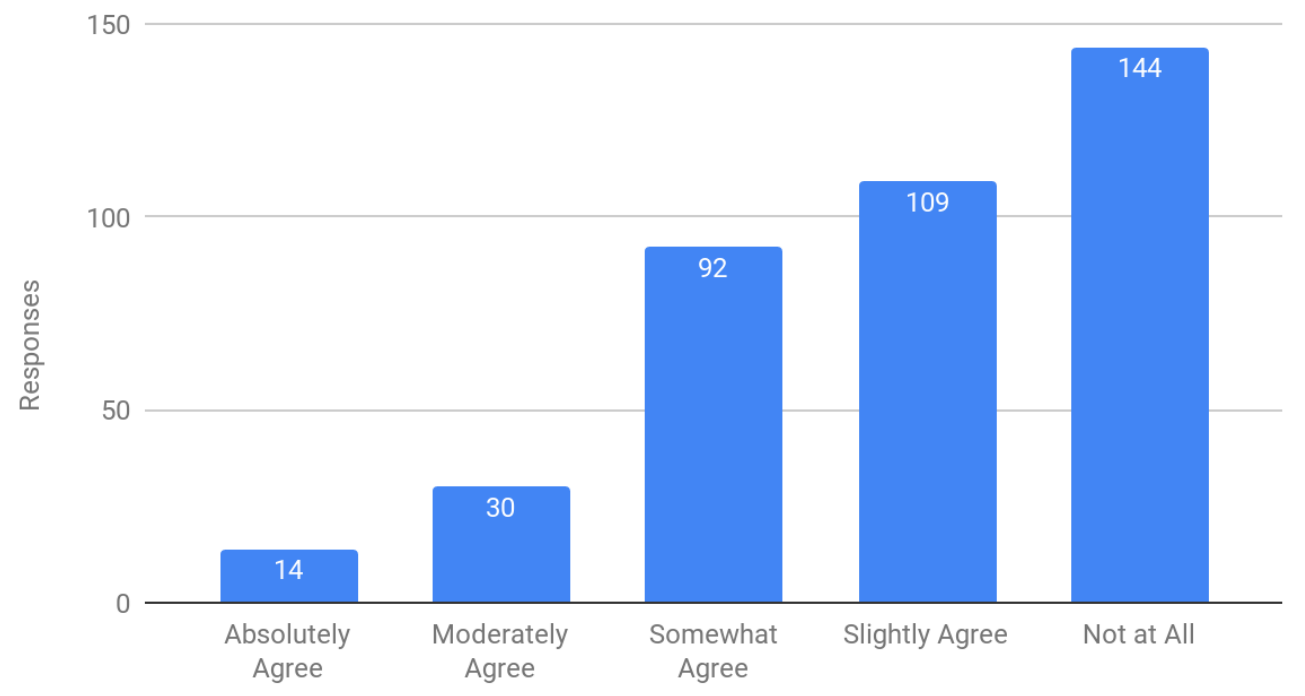

Figure 2. Question 23: Religion is Dangerous $(N=389)$.

In addition to the 389 quantitative responses received, 185 qualitative responses were recorded as open text comments. Manual multiple coding was independently undertaken by the three named authors. Independent first cycle descriptive coding was undertaken. Collaborative second cycle coding followed, resulting in 23 agreed thematic codes. The following codes were applicable to $10 \%$ or more of the data (Cf. Table 2):

Table 2. Question 23: Religion is Dangerous: Coding.

\begin{tabular}{lll}
\hline \multicolumn{1}{c}{ Code } & Occurrence & \% Total Responses \\
\hline Essentialism & 73 & 39.45 \\
Dangerous People & 60 & 32.43 \\
Instrumentalism & 51 & 27.56 \\
Dangerous Interpretations & 43 & 23.24 \\
Religion is not Dangerous & 38 & 20.54 \\
Extremism & 24 & 12.97 \\
Religion can be Dangerous & 21 & 11.35 \\
\hline
\end{tabular}


Essentialism, the key focus of this paper, is not precluded by other coded comments. For example, one Respondent states only that "People are dangerous" in response to Question 23: "Religion is dangerous". This answer is consistent, however, with fuller responses in the dataset in which a contrast is made between religion which is not dangerous (but is essentially good), and dangerous people. However, caution was exercised. Rather than coding it as both "Essentialism" and "Dangerous People", it was solely coded as the latter.

Of the 73 occurrences of Essentialism, 72 implied that religion was essentially good, while 1 implied that is was essentially bad. A further 7 (or 3.78\%) responses (all from Respondents within the Secondary sector) were explicitly non-essentialist, for example:

[Codes: Non-Essentialist; Dangerous People] I don't think that religion is good or bad, safe or dangerous. I think that individual people are good or bad [Secondary English State School Teacher]

[Codes: Non-Essentialist; Dangerous People] Lions are dangerous. So are people. Religion can't be dangerous as it isn't an actor. However, as with many ways of thinking, we have to acknowledge that religion can be a contributory factor in people becoming dangerous. [Secondary English State School Teacher]

Conceptualizing religion as essentially good/peaceful/pro-social did not preclude religion being potentially understood as dangerous; however, such danger can be the result of the "misuse" or misinterpretation of sacred texts by "extremist people", and "judging":

[Codes: Essentialism; Extremism; Dangerous Interpretations] All religions are peaceful. It's certain extremist people who misuse/misinterpret religion to create barriers and hate amongst people. [Primary/Junior English State School Teacher]

[Codes: Essentialism; Extremism; Dangerous Interpretations] We teach general tolerance to all people, of all religions and that all religions teach peace, love and compassion, with the odd exception where there may be extremists who misinterpret their holy books, but that they exist within all religions and that they are not true followers. [Secondary English Academy/Free School Teacher]

[Codes: Essentialism; Religion can be Dangerous] All religions want a loving a peaceful world where we all do what is right. It becomes dangerous only when religions start judging each other. We all worship God Almighty but religion allows people to do this in different ways. [Primary/Junior English State School Teacher]

The danger that people pose is a recurrent theme (60 incidents). In some incidences, dangerous people take religion, which is essentially "peaceful" —and make it dangerous:

[Codes: Dangerous People; Essentialism; Instrumentalism] I think that people choose to use religion in a dangerous way, to support their own beliefs, but that religion itself is not intrinsically dangerous. I cannot think of a religion that actively supports dangerous ideals. [Primary/Junior English State School Teacher]

[Codes: Essentialism; Dangerous Interpretations; Dangerous People] Religion is only dangerous if a "follower" makes it so. Religions are peaceful, interpretations of followers are dangerous. [Secondary Scottish State School Teacher]

[Codes: Dangerous People; Essentialism] It's people who are dangerous when they change religious texts to fit in with their own ideology not religion itself. [Secondary Scottish State School Teacher] 
[Dangerous People; Essentialism] People are dangerous, not religion. [Secondary English Academy/Free School Teacher]

Religion is not dangerous; rather, people are; and it is they who "pervert" religion making it "violent":

[Codes: Dangerous People; Essentialism; Religion is not Dangerous] It is people that [Sic.] pervert religion that [Sic.] can be violent, not the religion. [Secondary English State School Teacher]

In some of the responses, "religion" is considered "not dangerous". While a connection between religion and violence is accepted, it is reconciled by some through instrumentally conceiving of religion as a "tool" which "dangerous people" use to "incite violence":

[Codes: Religion is not Dangerous; Essentialism; Instrumentalism; Dangerous People] Religion is not dangerous-it is merely a tool used by dangerous people in an attempt to justify their actions. If people were not using religion to incite violence, they would use something else. Religion is not dangerous-people are dangerous. [Secondary English Academy/Free School Teacher]

[Codes: Dangerous Interpretations; Essentialism; Instrumentalism] Wrong understanding, or wrong interpretation of religion is dangerous. No religion advocates violence per se, but all can be/have been used that way in human history. [Primary/Junior English State School Teacher]

More passively, a lack of education can ultimately make religion dangerous by resulting in "misunderstanding and intolerance":

[Codes: Essentialism; Lack of Education; Religion can be Dangerous] Lack of education about other religions leads to misunderstanding and intolerance, which is what makes religion dangerous; not religion itself. [Primary/Junior English Independent School Teacher]

Given it might be assumed that atheists would more likely than theists view religion as dangerous, it is worth considering Respondents' self-identification in this regard. Question 15 explored UK RE teachers' (a)theistic beliefs: "Concerning Belief in God(s), are you?". Response options were: "Theist"; "Agnostic"; "Atheist"; and "Other", this latter option providing a free-text option to allow for a high-degree of specificity of response. Of the 431 quantitative responses (England: 303 responses or $70.30 \%$; Northern Ireland: 4 responses or $0.93 \%$; Scotland: 116 or $26.91 \%$; Wales: 5 or $1.16 \%$; and Other European Union Countries [Excluding Republic of Ireland]: 3 or $0.70 \%$ ): 196 (or 45.48\%) identified as a "Theist"; 134 Respondents (or 31.09\%) as an "Agnostic"; and 78 (or 18.10\%) as an "Atheist". A further 23 Respondents selected "Other" and noted a range of self-identifications, for example, from "impersonal transcendent" and "religious atheist", to "Panentheistic agnostic".

When Question 15 is cross-tabulated with Question 23 (356 responses), we can see (in Table 3) that while the majority of Atheists "Slightly Agree" that "Religion is dangerous", the majority of "Agnostics" and "Theists" respond: "Not at all". As such, considerations of the relative danger posed by religion (Question 23) do not correspond to Atheism, or the inverse to Theism (Cf. Table 3).

Beyond (a)theistic belief, Figure 3 shows the religious composition of the Respondents, the majority of whom self-identify as "Christian" $(n=200)$, with "no religion" as the second largest group $(n=196)$. 
Table 3. Question 15 Concerning Belief in God(s), are you? Cross-tabulated with Question 23: Religion is Dangerous.

\begin{tabular}{lrrrrrr}
\hline & $\begin{array}{c}\text { Absolutely } \\
\text { Agree }\end{array}$ & $\begin{array}{c}\text { Moderately } \\
\text { Agree }\end{array}$ & $\begin{array}{c}\text { Somewhat } \\
\text { Agree }\end{array}$ & $\begin{array}{c}\text { Slightly } \\
\text { Agree }\end{array}$ & Not at all & Total \\
\hline Q15: & $7.46 \%$ & $11.94 \%$ & $22.39 \%$ & $\mathbf{3 1 . 3 4 \%}$ & $26.87 \%$ & $18.82 \%$ \\
Atheist & 5 & 8 & 15 & $\mathbf{2 1}$ & 18 & 67 \\
\hline Q15: & $1.69 \%$ & $5.93 \%$ & $28.81 \%$ & $27.12 \%$ & $\mathbf{3 6 . 4 4 \%}$ & $33.15 \%$ \\
Agnostic & 2 & 7 & 34 & 32 & $\mathbf{4 3}$ & 118 \\
\hline Q15: & $1.75 \%$ & $5.85 \%$ & $20.47 \%$ & $29.24 \%$ & $\mathbf{4 2 . 6 9 \%}$ & $48.03 \%$ \\
Theist & 3 & 10 & 35 & 50 & $\mathbf{7 3}$ & 171 \\
\hline
\end{tabular}

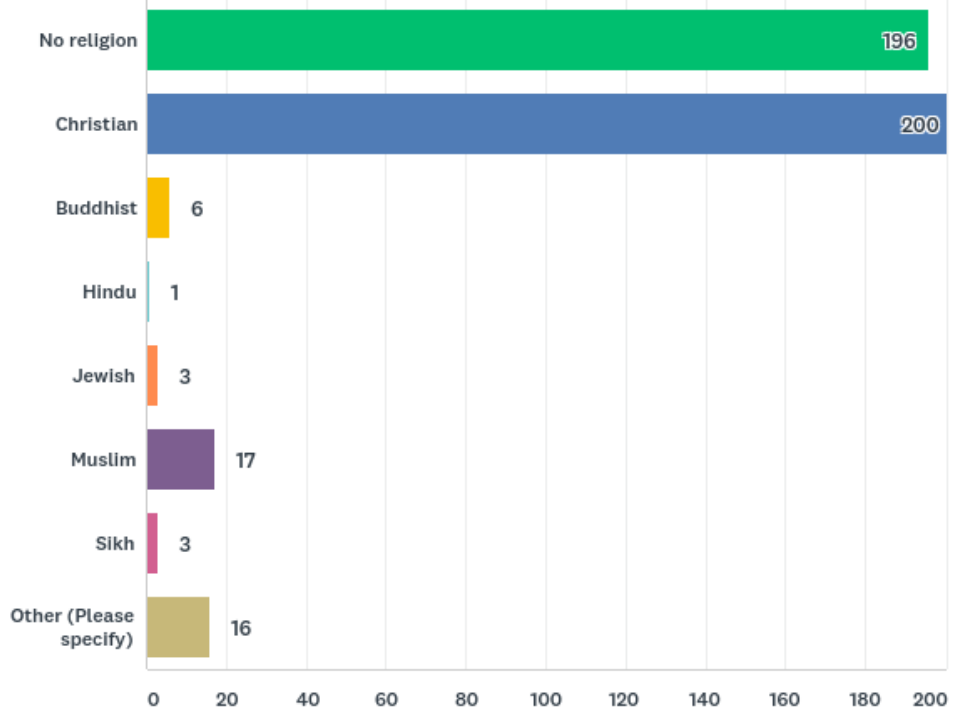

Figure 3. Question 16: What is your Religion? $(N=442)$

\subsection{Question 24: "Religion Should Be Taught in A Positive Way in RE"}

A total of 386 Respondents used a unipolar 5-point Likert scale to respond to the statement: "Religion should be taught in a positive way in RE", "Religion" being employed as a collective noun. The majority of Respondents chose "Absolutely Agree" ( $N=231$ or 59.84\%). In total, 386 quantitative responses were received (Cf. Figure 4):

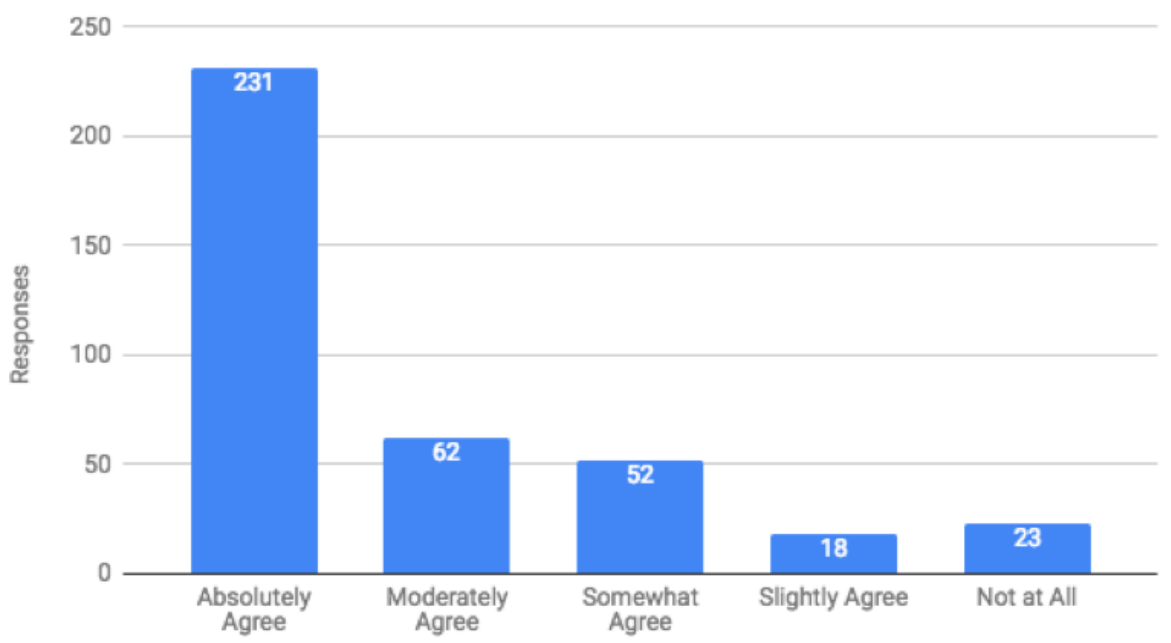

Figure 4. Question 24: Religion Should be Taught in a Positive Way in RE $(N=386)$. 
In addition to the quantitative responses, 137 qualitative responses were recorded as open text responses. Manual multiple coding was independently undertaken by the three named authors. Independent first cycle descriptive coding was undertaken. Collaborative second cycle coding followed, resulting in 27 agreed thematic codes. The following codes were applicable to $10 \%$ or more of the data (Cf. Table 4).

Table 4. Question 24: Religion should be taught in a positive way in RE: Coding.

\begin{tabular}{lll}
\hline \multicolumn{1}{c}{ Code } & Occurrence & \multicolumn{1}{c}{$\%$ Total Responses } \\
\hline Positive and Negative Presentations & 48 & 35.03 \\
Taught Positively & 30 & 21.89 \\
Criticality & 26 & 18.97 \\
Objectivity & 20 & 14.59 \\
Essentialism & 13 & 9.48 \\
\hline
\end{tabular}

Of the 137 qualitative responses, 48 maintained that religion should be presented both positively and negatively. In 11 of these 48 responses, an essentialist concept of religion underpins the response: as religion is essentially positive, it should be taught as such:

[Codes: Religion is Positive; Positive and Negative Presentations; Essentialism] Religion is a positive, loving entity and thus should be taught as such. This doesn't mean negative elements should be left out, but the overarching feeling should be positivity. [Secondary English State School Teacher]

The negative aspects of religion should be acknowledged; however, they can be a distortion—distorted by "minority groups" or "those in authority"-which requires an understanding of religion that is essentially positive:

[Codes: Essentialism; Instrumentalism; Religion is Positive] We need to accept that some aspects of religion can be taken in a negative way and deal with these issues, however, it should always be underlined that these are tiny minority groups distorting religious doctrine. [Secondary English Academy/Free School Teacher]

[Codes: Essentialism; Instrumentalism] I would say that one needs to learn to see how religion is being used by those in authority to create discord in the world and within our communities. Children need to know about Religion and what it says and how it is being manifested in the world ... school needs to do this, because I don't think parents can do this. [Secondary Scottish State School Teacher]

In other responses, as noted in relation to Question 23, religion is understood as a "tool for life" that can be misused; misuse implying a correct, positive in context, use:

[Codes: Positive and Negative Presentations; Essentialism] It's a complex subject. Religion is a tool for life. Tools can be misused and so both the positives and negatives need to be explored to ensure proper use of the tool. This can be done in a positive way but the pitfall of dumbing down should be avoided. [Secondary English Academy/Free School Teacher]

If taught correctly, it would "counteract" prejudice and discrimination, implying that faith is essentially anti-discrimination:

[Codes: Bias; Essentialism; Media] Correct teaching of faiths would counteract prejudices and choices of discriminatory behavior among some of our society. A perception based on poor reporting, unsubstantiated media and preconceived ideas needs to be challenged with true, unbiased responsible teaching. [Secondary English State School Teacher] 
Thirty responses maintained that religion should be taught positively within RE (Coded: Taught Positively). For some (26 coded responses), RE should be taught critically and objectively (20 coded responses).

While the "positive impact on human lives should definitely be taught" within RE, critical skills (coded: Criticality) are also required and are embedded within RE:

[Codes: Criticality; Essentialism; Instrumentalism; Taught Positively] The positive impact on human lives should definitely be taught. However, so should the critical skills needed to discern when religion is being used to promote inhuman or immoral conduct or attitudes. [Secondary English Academy/Free School Teacher]

[Codes: Criticality] RE is about the critical study of religion. [Secondary Northern Irish State School Teacher]

[Codes: Choice; Criticality; Objectivity] Religion should be taught about factually, in an objective manner. Students should be encouraged to critically evaluate religious concepts and beliefs for themselves to determine whether a particular religion is "positive". [Secondary English Independent School Teacher]

[Codes: Criticality] RE must include critical thinking and philosophy encouraging pupils to think independently i.e., atheist and agnostic views must be part of lessons. [Secondary English State School Teacher]

[Codes: Criticality; Dangerous Interpretations] Religious studies must encourage students to be critical. There are issues which cannot be ignored that stem from interpretations etc. of religious teachings. We do not have to respect all beliefs, we should engage critically and encourage our students to do the same, drawing conclusions and views on teaching and practices that are reasoned and justified. I would not teach children to "respect" or view positively the issue of child marriage or FGM as it is a practice tied to religion or culture. I would present them with the information and let them decide if it is a belief to be challenged or respected. [Secondary Scottish State School Teacher]

In this instance, criticality is linked to an essentialist understanding of religion as pro-human; pro-moral: arguably, critical skills enabling one to identify when religion is being "used" for ill. Others disagree: religion should be taught neutrally as a "phenomenon":

[Codes: Bias, Neutrality] It should be taught in a neutral way but it's usually taught as positive. I teach it as a phenomenon, not a guide. It seems that most RE teachers and resources tend to pick the nice bits and shy away from some controversies, especially in primary schools and faith schools. Children are guided towards a biased understanding of religion. (Primary/Junior English State School Teacher)

\section{Discussion}

This research raises significant questions for RE in the UK, and beyond, concerning the purpose(s), pedagogy, and content of RE; the need for RE teachers to have adequate subject content knowledge; the centrality of critical and complex approaches; and perhaps most pressingly, about how religion is conceptualized, presented, and discussed, within the RE classroom.

We argue that a non-essentialized, non-sanitized, RE is needed which is conceptually able to nuance religious diversity-both across, and within, religions. Such an RE requires a critical and judicious use of RE textbooks, for example, some of which erroneously encourage the adoption of essentialist conceptualizations of religion:

It is indisputable that the suicide-bombers derive inspiration and comfort from their reading of the Qur'an. It is therefore peculiarly important that a true and fair reading is taught. 
For the problem in a nutshell is this: that there are verses in the Qur'an-as there are in the Bible-which, taken out of context and without regard for the import of the Qur'an as a whole, do justify hatred and violence... The overwhelming import of both Bible and Qur'an is pro-love and anti-violence. (Watson and Thompson 2006, p. 149 [Emphasis added])

A non-essentialist understanding of religion will not only improve religious understanding, but it will enable RE to meet its extrinsic and intrinsic goals: to enhance social cohesion; and to present religions and beliefs with academic integrity.

As recognised, there are complex and manifold expectations placed upon UK RE. This paper reveals that some UK RE teachers' presentation of religion is closely aligned to policy goals, such as the fostering of tolerance and respect. While, arguably, such values have a clear place in education; academic integrity requires that religion (and indeed, all ideologies) is presented as a complex spectrum of beliefs and behaviors which resist reduction to simplistic articulations. Furthermore, to present all religion as pro-social may lead to cognitive dissonance in at least some learners, who see religion contribute not only to human flourishing, but also to human harm. A lesser, but no less undesirable, potential consequence of classroom presentations failing to cohere with the complex realities of religion, is that learners may (with some justification) believe that they cannot trust what they are taught about in RE.

The essentializing and sanitizing views put forward by some UK RE teachers distort religion and inadvertently foster misunderstanding. This is not only bad educationally, but, following Barnes (2009), it is likely an ineffective, and certainly an unsustainable, means to cultivate tolerance and respect. Barnes further argues that adherents whose beliefs and practices are not represented in the classroom (because they are non-essentialist conceptualizations) are not being respected. Should learners realize that they are not being represented, "[t]hey will conclude that there is no real respect for difference" (2009, p. 43).

In terms of sustainability, Barnes argues that essential sameness of religion as a basis for tolerance and respect carries the implication that difference is inversely related to respect. This poses the question: if respect and tolerance are based upon essential sameness, what happens when we are faced with differences; both within, and between, religions? Barnes does not deny that RE has the potential to contribute to respect and tolerance, rather he argues:

This potential will only be realized ... when educators fully acknowledge the "intractable" nature of religious difference and implement strategies and policies that predicate respect for others on personhood rather than on theological assumptions about the essential agreement between religions and between religious adherents. (Barnes 2009, p. 17)

In the light of our research, learners require to be educated to be able to consider, and to explore, what hermeneutical limits (if any) may be placed on manifestations of religion: to what extent (if at all) putative family resemblances may enable the talk of religion as a common, and meaningful, cluster of belief and practice; and whether these beliefs and behaviors are, or are not, beneficial to community life and human flourishing. In short, children and young people need to learn how to be able to resist and condemn anti-social articulations of religion which engender human harm, without resorting to crude essentialism. A mature understanding of religion is required which is able to encompass, and to reflect, the very best and worst of religious expression, and all of the shades of the spectrum in-between.

\section{Religious Literacy?}

Diverse writers such as Wright (1993, 2004); Sahin (2017); Richardson (2017); Prothero (2008); Moore (2007, 2016); Francis and Dinham (2016); and Conroy (2016); have contributed to discussion on the need for, and nature of, religious "literacy".

According to Wright, religious literacy is "the ability ... to reflect, communicate and act in an informed, intelligent and sensitive manner towards the phenomenon of religion" (Wright 1993, p. 47). 
Moore (2016) offers a definition which places emphasis on a sensitivity to context, diversity, plurality and complexity.

Richardson (2017, p. 364) formulates religious literacy as "an individual and social good, from the ability of individuals to make informed choices about the beliefs that influence their moral understandings, to the moral goods of increasing understanding respect and tolerance, and responsible political and civic engagement". Implied within such an understanding is the notion of religious literacy as a discerning response to, and understanding of, religious phenomena, as they manifest set against fluid and changing socio-politico, cultural, and historical contexts.

Religious "literacy" is a contested term: notwithstanding, any improvement in religious understanding (religious literacy) requires that religion is presented as multifarious. The "harmfulness", or (de)merits of some forms of religion to individuals and society can still be argued for. However, this understanding is not predicated upon a conceptualization of harmful religion as "false" religion (Unless "false" is used as a synonym for "undesirable").

\section{Recommendations}

This paper concludes with some recommendations to enhance the fostering of a religious literacy which rejects the simplistic and erroneous binary between good/true/genuine religion and bad/false religion. These recommendations are primarily aimed at those involved in RE Teaching, RE Teacher Education, RE policy formation, and the writing of RE materials:

- Educate teachers and learners, and encourage them, to recognize and critique essentialist representations of religion;

- Avoid using essentialist expressions, such as "Hindus believe ... " in favor of "while some Hindus believe, others ..." " or "the majority of Hindus believe ... while a minority believe ... ";

- Embed the concept of religious plurality through the use of terms, such as "Christianities", "Islams", etc.;

- Emphasize diverse religious expressions: beliefs, practices, and attitudes, within and across religious traditions and communities;

- Use a range of images in lesson resources and classroom displays which reflect religious diversity;

- Create a dialogic space, being prepared to "pause" the lesson to discuss issues, examples, and experiences of religious diversity;

- Arrange encounters with diverse representations through visitors, visits, and video clips; for example, invite three Buddhists rather than one to talk about what the concept of rebirth means to them;

- Avoid using stereotypical images of religious people—for example, only showing Muslim women wearing headscarves;

- Explicitly consider religious diversity, and where relevant where these intersect with other forms of diversity, when devising learning aims and intended learning outcomes;

- Avoid crude equivalences between religions, for example, the Qur'an is the Muslim Bible;

- Avoid giving narrative privilege to any particular denominations/sect/spokesperson, for example, presenting the Dalai Lama as the leader of Buddhism globally;

- Ensure clear distinctions between the purpose(s) of RE and any religious activity in schools (in particular religious observance/worship) as there is evidence of an ongoing conflation of the two (Nixon 2018) which perpetuates essentialism.

The writers of this paper intend to add to these recommendations as part of following up the current research by exploring, through other areas of the dataset, the faith/ideological position of RE teachers; degree qualifications, and attitudes and approaches they have to world religions and ethical issues, as well as perspectives on (what should be) the aim(s) of RE. 


\section{Conclusions}

A clear essentializing motif is evident in some UK RE teachers' conceptualizations of religion. Rather than an abstract nicety, this approach not only erects a barrier to the understanding of religion as a diverse, and rich, phenomenon, but it conceptually impoverishes children and young people, by replacing RE with a shallow alternative unfit to make sense of the world. In the pursuit of understanding, children and young people need to learn how to be able to resist and condemn anti-social articulations of religion which engender harm, without resorting to crude essentialism. A mature understanding of religion is required which is able to encompass, and to reflect, the very best and worst of religious expression-and all of the shades of the spectrum in-between. While this makes the UK RE teachers' task all the more challenging, it also re-affirms the educational value of RE and its rightful place within the curricula of the UK.

Author Contributions: At all stages of the research process involved in the writing of this paper, from initial hypothesis to design and deployment of the national survey, to coding, analysis and writing, all three authors were relatively equally involved. That said it is fair to say that the balance of involvement is indicated by author order.

Funding: This research received no external funding.

Conflicts of Interest: The authors declare no conflict of interest.

\section{References}

Adib-Moghaddam, A. 2009. A Metahistory of the Clash of Civilisations: Us and Them beyond Orientalism. London: Hurst. Baldick, C. 2008. The Oxford Dictionary of Literary Terms, 3rd ed. Oxford: Oxford University Press.

Banks, R. 1974. Matthew's Understanding of the Law: Authenticity and Interpretation in Matthew 5:17-20. Journal of Biblical Literature 93: 226-42. [CrossRef]

Barnes, P. L. 2009. Religious Education: Taking Religious Difference Seriously. Impact Special Issue 17: 9-56. [CrossRef]

Cameron, D. 2017a. Extremism Speech. The Independent Newspaper. Available online: https:/ /www.independent. co.uk/news/uk/politics/david-cameron-extremism-speech-read-the-transcript-in-full-10401948.html (accessed on 23 September 2018).

Cameron, D. 2017b. Lord Mayor's Speech. Available online: https://www.gov.uk/government/speeches/lordmayors-banquet-2015-prime-ministers-speech (accessed on 12 September 2018).

Cavenaugh, W. 2004a. Terrorist Enemies and Just War. Christian Reflection 12: 27-35.

Cavenaugh, W. 2004b. The Violence of 'Religion': Examining a Prevailing Myth. Working Paper No. 310. Available online: http:/ / www.nd.edu/ kellogg/publications/workingpapers/WPS/310.pdf (accessed on 12 July 2018).

Conroy, J. C., D. Lundie, R. A. Davis, V. M. Baumfield, L. P. Barnes, T. Gallagher, K. Lowden, N. Bourque, and K. Wenell. 2013. Does RE Work? A Mutli-Dimensional Investigation. London: Bloomsbury.

Conroy, J. C. 2016. Religious Education and Religious Literacy-A Professional Aspiration? British Journal of Religious Education 38: 163-76. [CrossRef]

Council for the Curriculum, Examinations and Assessment. 2015. Religious Education. Available online: http: / / ccea.org.uk/curriculum/key_stage_1_2/areas_learning/religious_education (accessed on 13 May 2018).

Schools Council. 1971. Working Paper 36: Religious Education in Secondary Schools. London: Evan/Methuen.

Dalai Lama. 2016. Speaking at the European Parliament in Strasbourg in France. The Independent Newspaper. Available online: https: / www.independent.co.uk/news/people/dalai-lama-muslim-terrorism-islam-nosuch-thing-as-video-watch-speech-a7317001.html (accessed on 21 August 2018).

Department for Education. 2017. School Workforce in England. Available online: https://www.ethnicityfactsfigures.service.gov.uk/workforce-and-business/workforce-diversity/school-teacher-workforce/ latest (accessed on 7 November 2018).

Scottish Education Department. 1972. Moral and Religious Education in Scottish Schools; Edinburgh: Scottish Education Department. 
Department for Children, Schools and Families. 2010. Religious Education in English Schools: Non Statutory Guidance. Available online: https:/ /assets.publishing.service.gov.uk/government/uploads / system/uploads/attachment_data/file/190260/DCSF-00114-2010.pdf (accessed on 13 May 2018).

Dunn, J. D. G. 2015. Neither Jew nor Greek: Christianity in the Making, Volume 3. Grand Rapids: Wm B. Eerdmans.

Department of Education. 2015. The Prevent Duty Departmental Advice for Schools and Childcare Providers. Available online: https:/ / assets.publishing.service.gov.uk/government/uploads/system/uploads/attachment_ data/file/439598/prevent-duty-departmental-advice-v6.pdf (accessed on 24 September 2018).

Eickelman, D., and J. Piscatori. 1996. Muslim Politics. Princeton: Princetown University Press.

The Office for Security and Co-Operation in Europe. 2007. Toledo Guiding Principles on Teaching about Religon and Belief in Public Schools; Warsaw: Office for Democratic Institutions and Human Rights.

Evangelical Alliance Commission on Unity and Truth among Evangelicals. 2000. The Nature of Hell. London: Acute/Paternoster.

Fitzgerald, T. 1997. A Critique of the Concept of Religion. Method and Theory in the Study of Religion 9: 91-110. [CrossRef]

Francis, M., and A. Dinham. 2016. Religious Literacies: The Future. In Religious Literacy in Policy and Practice. Bristol: Policy Press.

Garland, D. E. 2003. 1 Corinthians. Grand Rapids: Baker Academic.

Scottish Government. 2008. Curriculum for Excellence, Religious and Moral Education Principles and Practice Paper. Available online: https:/ / education.gov.scot/Documents/rme-pp.pdf (accessed on 7 June 2018).

Welsh Assembly Government. 2017. National Exemplar Framework for Religious Education for 3 to 19-Year Olds in Wales. Available online: http:/ / learning.gov.wales/docs/learningwales/publications/130426-renational-exemplar-framework-en.pdf (accessed on 13 May 2018).

Gunning, J. 2007. A Case for Critical Terrorism Studies? Government and Oppositions 42: 363-93. [CrossRef]

Gunning, Jeroen, and Richard Jackson. 2011. What's so 'religious' about 'Religious Terrorism'? Critical Studies on Terrorism 4: 369-88. [CrossRef]

Hasenclever, A., and V. Rittberger. 2000. Does Religion Make a Difference? Theoretical Approaches to the Impact of Faith on Political Conflict. Millemium 29: 641-74. [CrossRef]

Hashim, Ahmed S. 2014. The Islamic State: From Al-Qaeda Affiliate to Caliphate. Middle East Policy 21: 69-83. [CrossRef]

Hitchens, C. 2008. God Is Not Great: How Religion Poisons Everything. London: Atlantic Books.

Hoffman, B. 2006. Inside Terrorism. Columbia: Columbia University Press.

Lee, P. 2011. Historical Literacy and Transformative History. In The Future of the Past: Why History Education Matters. Edited by L. Perikleous and D. Shelmit. Nicosia: Kailas.

Martin, D. C. 1993. The New Moses-A Matthean Typology. Edinburgh: T \& T Clark.

Martin, D. C. 2013. The End of the Ages Has Come: An Early Interpretation of the Passion and Resurrection of Jesus. Eugene: Wipf and Stock.

Masters, D. 2008. The Origin of Terrorist Threats: Religious Seperatist, or Something Else? Terrorism and Political Violence 20: 396-414. [CrossRef]

Moore, D. 2007. Overcoming Religious Illiteracy: A Cultural Studies Approach to the Study of Religion in Secondary Education. New York: Palgrave MacMillan.

Moore, D. 2016. Diminishing Religious Literacy: Methodological Assumptions and Analytical Frameworks for Promoting the Public Understanding of Religion. In Religious Literacy in Policy and Practice. Edited by A. Dinham and M. Francis. Bristol: Policy Press.

Nixon, G. 2013. Religious Education on the Darkling Plain: The Emergene of Philosophy within Scottish Religious Education. Saarbrucken: Lambert Academic Publishing.

Nixon, G. 2018. Conscientious Withdrawal from Religious Education in Scotland: Anachronism or Necessary Right? British Journal of Religious Education 40: 6-19. [CrossRef]

Obama, B. 2016. Why I Won't Say Islamic Terrorism. Available online: https:/ / edition.cnn.com/2016/09/28/ politics / obama-radical-islamic-terrorism-cnn-town-hall/index.html (accessed on 23 September 2017).

Panjwani, F., and L. Revell. 2018. Religious Education and Hermeneutics: The Case of Teaching about Islam. British Journal of Religious Education 40: 268-76. [CrossRef]

Pape, R. A. 2005. Dying to Win: The Strategic Logic of Suicide Terrorism. London: Random House.

Paul, P. J., II. 1994. Catechism of the Catholic Church. London: Geoffrey Chapman. 
Prothero, S. 2008. Religious Literacy, What Every American Needs to Know. New York: Harper Col.

Rapoport, David C. 1983. Fear and Trembling: Terrorism in Three Religious Traditions. American Political Science Review 78: 658-77. [CrossRef]

Revell, L. 2012. Islam and Education: The Manipulation and Misrepresentation of a Religion. London: Institute of Education Press.

Richardson, N. 2008. Faith Schooling: Implications for Teacher Educators. A Perspective from Northern Ireland. Journal of Beliefs and Values 29: 1-10. [CrossRef]

Richardson, N. 2017. Religious Literacy, Moral Recognition, and Strong Relationality. Journal of Moral Education 46: 363-77. [CrossRef]

Riches, J. 1996. Matthew. Sheffield: Sheffield Academic Press.

Robinson, G. 1997. Building a Palestinian State: The Incomplete Revolution. Indianapolis: Indiana University Press.

Sageman, M. 2011. Understanding Terror Networks. Philadelphia: University of Philadelphia Press.

Sahin, A. 2017. Religious Literacy, Interfaith Learning and Civic Education in Pluralistic Societies. In Interfaith Education for All. Rotterdam: Sense Publishers, pp. 45-53.

Sayyid, S. 2003. A Fundamental Fear: Eurocentrism and the Emergence of Islamism. London: Zed Books.

Schaffalitzky de Muckadell, C. 2014. On Essentialism and Real Definitions of Religion. Journal of the American Academy of Religion 8: 495-520. [CrossRef]

Commission on Religious Education in Schools. 1970. The Fourth R: The Report of the Commission on Religious Education in Schools. London: Commission on Religious Education in Schools.

Sedgwick, M. 2010. Al-Qaeda and the Nature of Religious Terrorism. Terrorism and Political Violence 16: 795-814. [CrossRef]

Smith, D. 2009. Hand This Man over to Satan: Curse, Exclusion and Exclusion and Salvation in 1 Corinthians 5. London: Bloomsbury.

Smith, J. 2018. Identity and Instrumentality: History in the Scottish School Curriculum 1992-2017. Historical Encounters: A Journal of Historical Consciousness, Historical Cultures, and History Education 5: 31-45.

Smith, Wilfred Cantwell. 1962. The Meaning and End of Religion: A New Approach to the Religious Traditions of Mankind By. New York: Macmillam.

Temple, W. 1924. Christus Veritas. London: Macmillan.

Watson, B., and P. Thompson. 2006. The Effective Teaching of Religious Education. Oxon: Routledge.

Winant, H. 2004. The New Politics of Race: Globalism, Difference, Justice. Minneapolis and London: University of Minnesota Press.

Wright, A. 1993. Religious Education in the Secondary School: Prospects for Religious Literacy. London: Fulton.

Wright, A. 2004. The Justification of Compulsory Religious Education: A Response to Professor White. Religious Education 26: 165-74. [CrossRef]

(C) 2018 by the authors. Licensee MDPI, Basel, Switzerland. This article is an open access article distributed under the terms and conditions of the Creative Commons Attribution (CC BY) license (http:/ / creativecommons.org/licenses/by/4.0/). 